\title{
Does Organizational Culture and Digital Technology influence Behavioral Innovation in Millennial Generation?
}

\author{
L C Nawangsari ${ }^{1}$, A H Sutawidjaya ${ }^{2}$ \\ 1,2Universitas Mercu Buana \\ 1ㄹenny.christina@mercubuana.ac.id, ${ }^{2}$ a.h.sutawijaya@mercubuana.ac.id
}

\begin{abstract}
In the midst of rapid technological growth among millennials, there are matters of special concern, namely organizational culture and behavioral innovation. The role of millennial generation becomes an inseparable part of the present. Digitalization and the revival of millennials demand different organizations because in the digital era like today, a new set of views is needed, one of them about culture and innovation. This study uses quantitative methods to analyze digital technology and organizational culture that influence behavior innovation in millennial generations. The study population is employees who enter into the millennial generation. The research sample of 75 respondents. Data collection used were questioner and observation. Research data were processed using SEM. The results showed that digital technology and organizational culture had a positive effect on behavioral innovation in millennial generation.
\end{abstract}

Keywords: Millennial Generations; Technological Digital; Organization Culture.

\section{INTRODUCTION}

Corporate / organizational culture is very important in creating fluency in all aspects that run in the company. Corporate culture is the foundation that contains the norms, values, work methods of employees and habits that lead to the quality of organizational performance. Corporate culture is a reflection of the behavior of higher-ups in the company. Many employees do not really understand the true meaning of company culture. What many thoughts cross the minds of employees, corporate culture is an attitude or behavior that is shown by the leaders in their place of work. Concept of culture originally derived from a metaphor of the organisation as 'something cultivated. Schein highlights that 'the only thing of real importance that leaders do is to create and manage culture [1]; that the unique talent of leaders is their ability to understand and work with culture; and that it is an ultimate act of leadership to destroy culture when it is viewed as dysfunctional' 


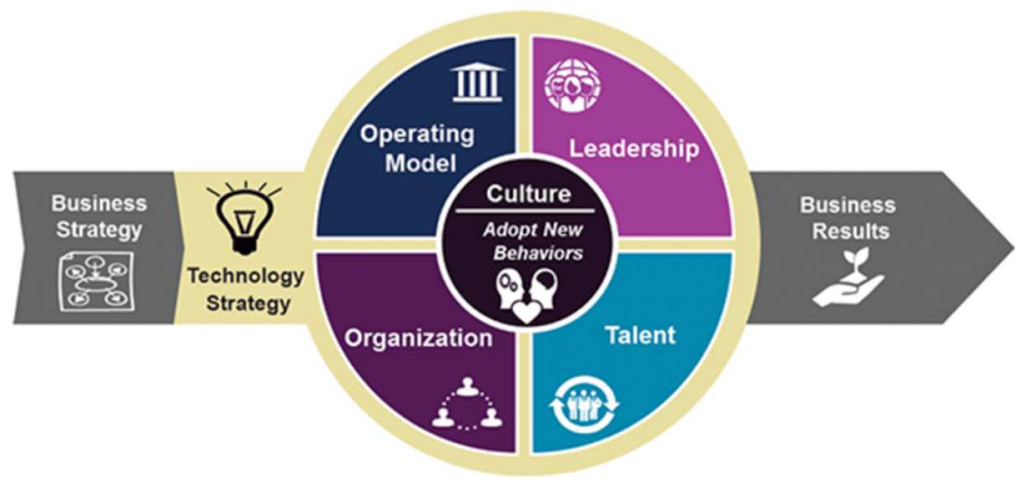

FIGURE 1. Framework culture digital

The development of Information Technology in the era of modernization has an enormous influence in many fields, including organizational culture, which is affected by the progress and rapid development of technology. Organizational culture is a system of shared meanings shared by members that distinguishes an organization from other organizations. This shared meaning system is a set of key characteristics that are held in high esteem by the organization. The issue of technological development is the behaviour of people's lives. This is because, rapid changes in information technology have changed the culture of most Indonesian people, technological progress consciously or unconsciously has changed many patterns of people's lives. Politics in organizations thus inhibits change. More than 50 percent of lowperforming organizations feel that politics in the office is a major challenge in making change efforts more difficult. Stakeholder engagement is lacking, so there is no close relationship with employees. Three quarters (75\%) of high-performing organizations are able to empower decisions from below, being able to embrace and have programs that encourage togetherness.

The importance of the influence of technology on culture in organizations so that many organizations have lately recognized and realized that technology and culture can provide their own colour in the relationships between members in the organization and the joints of life of members of the organization.

Some previous research related to technology in organizational culture states that there is an influence between technology and organizational culture [2] [3][4]. Other research also states the influence of organizational culture on innovative behaviour [5][6] [7]. Innovative behaviour can also be grown through Knowledge Management in organizations [8].This research examines the interaction between organisational culture and digital technology influence behavioral innovation in millennial generation.

\subsection{Innovative behaviour}

Innovation is creating and implementing something into one combination. With innovation, one can add value to products, services, work processes, marketing, delivery systems, and policies, not only for companies but also stakeholders and the public [9]. De Jong defines innovation behaviour as an individual activity that aims to introduce new and useful ideas related to processes, products or procedures [10] Amabile states that the work environment that influences the behaviour of innovation must meet several provisions, namely a) provide encouragement to take risks, b) be fair and provide support for ideas, c) respect and recognize innovation, d) collaboration of ideas that continues to flow, and e) participates in making decisions.[11] 


\subsection{Organizational culture}

Culture distinguishes people from one another in the way they interact and act in complete works. Culture unites community members into one display of uniformity creating behaviour or action. Organizational culture is a system that is believed and values developed by organizations where it guides the behaviour of members of the organization itself. Schein stated organizational culture is the basic pattern accepted by organizations to act and solve problems, form employees who are able to adapt to the environment and unite members of the organization. For this reason, it must be taught to members, including new members, as a correct way to study, think and feel the problems encountered [12].

\subsection{Organizational Culture Function}

According to Robbins the function of organizational culture is as follows: a.) Culture creates a clear distinction between one organization and another. b.) Culture carries a sense of identity for members of the organization. c.) Culture makes it easy for commitment to something broader than one's individual self-interest. d.) Culture is the social glue that helps unite the organization by providing appropriate standards for employees. e.) Culture as a mechanism for making meaning and control that guides and shapes employee attitudes and behaviour [13]

\subsection{Technology Digital}

Berman \& Rice stated that Digital technology has redefined how people live. Technology is changing the traditional industry structure and reinterpreting what it means to be a customer and citizen [14]. Digital technologies show a variety of technologies, tools, services and applications using various types of hardware and software [14]. They facilitate the services or activities by electronic means to create, store, process, transmit and display information. In general, digital technology including the use of personal computers, digital televisions, radios, cell phones, robots, etc [15]. Digital technology solutions that are believed to have the potential to expand access, reduce costs, and improve the quality of education [16]. 'Digitization' is all about converting analogue information into digital information, while the 'digitization' refers to the use of digital technology to change business models and deliver new revenue-producing value and opportunities; it is the process of moving to digital business.. They argue that even though new technologies are often major factors, they have never been fully responsible for an industry on their own. Burita supports this view, noting that "technology doesn't provide value to a business, but that technology's value comes from doing business differently because technology makes it possible." Therefore, there is a need to look at industry transformation processes more holistically beyond the narrow prism of technology as the main influencing factor. Digital business transformation provides a much needed opportunity through digital technology adoption and adaptation of internal processes such as BPM and Lean Management and the business model to achieve the much needed flexibility in achieving the transformation organisational in the era of digital economy [17].

\section{RESEARCH METHOD}

This research used quantitative approach with survey method conducted on millennials employee in Jakarta with total sample counted 75 people. All variables in the study were measured using a Likert scale of 1-5.

\section{RESULTS AND DISCUSSION}


This study uses Generalized Structured Component Analysis (GSCA) developed by Hwang [19].

\subsection{Test Validity and Reliability}

Testing is done by conducting Discriminant Validity and Reliability as follows:

\section{Discriminatory validity}

TABLE 1. Discriminant validity test results

\begin{tabular}{lc}
\hline Variable & Average variance extracted (AVE) \\
\hline Digital Technology (X1) & 0.720 \\
Organizational Culture (Y1) & 0.726 \\
Innovative behaviour (Y2) & 0.690 \\
\hline
\end{tabular}

Source: Primary data processed (2019)

Table 1 above, shows the results of the discriminant validity test where all the values of Average variance extracted (AVE) are more than 0.50 . Thus it can be concluded that this measurement meets Convergent Validity requirements based on the value of Average Variance Extracted (AVE).

\section{Composite Reliability}

TABLE 2. Composite Reliability Testing Results

\begin{tabular}{lcc}
\hline \multicolumn{1}{c}{ Variable } & Composite Reliability & Explanation \\
\hline Digital Technology (X1) & 0.903 & Reliable \\
Organizational Culture (Y1) & 0.904 & Reliable \\
Innovative behaviour (Y2) & 0.875 & Reliable \\
\hline
\end{tabular}

Source: Primary data processed (2019)

Based on Table 2 above, it can be explained the results of composite reliability testing which shows satisfactory values, where all latent variables have been reliable because all of the variable values have composite reliability values $\geq 0.60$. In other words, the questionnaire used as an instrument in this study is reliable or consistent. Thus it can be concluded that, all indicators are indeed a measure of their respective constructs.

\subsection{Goodness of Fit Model}

The theoretical model in the conceptual framework of the study is said to be fit if it is supported by empirical data. There are two indications to see whether the model used is good, namely structural goodness of fit models and overall model goodness of fit. To find out that the hypothetical model of goodness of fit overall model is supported by empirical data presented in Table 3.

TABLE 3. Testing Results for Goodness Of Fit Overall Model

\begin{tabular}{clll}
\hline Criteria & Cut-of value & Model Results & Explanation \\
\hline SRMR & $\leq 0,08$ & 0.076 & Good Model \\
GFI & $\geq 0,90$ & 0.997 & Good Model \\
\hline
\end{tabular}

Source: Primary data processed (2019) 
The results of the Goodness of Fit Overall Model test based on Table 3 shows that SRMR and GFI have met the cut-off value, so the GSCA model in this study is suitable and feasible to use, so that interpretation can be made for further discussion.

Goodness of Fit The structural model is measured using FIT and AFIT. In this modeling the FIT value is obtained that is equal to 0.640 which means that the research model formed can explain all the existing variables of 0.643. The diversity of Digital Technology (X1), Organizational Culture (Y1) and Innovative behavior (Y2) that can be explained by the model is $64.30 \%$ and the rest $(35.70 \%)$ can be explained by other variables not included in the study. That is, if seen from the FIT value obtained, the model formed can be said to be good.

Adjusted from FIT is almost the same as FIT. However, because there are not only one variable that affects Sustainability Business, there are two variables, so it would be better if the interpretation of the accuracy of the model uses AFIT. AFIT formed from the structural model is 0.632 . So, the formed model can explain all the variables which are equal to 0.632 . The diversity of Digital Technology (X1), Organizational Culture (Y1) and Innovative behavior (Y2) which can be explained by the model is $63.20 \%$ and the rest $(37.80 \%)$ can be explained by other variables. That is, if seen from the AFIT value obtained, the model formed can be said to be still quite good.

\subsection{Variable Measurement Model}

Conversion of path diagrams into measurement models for each Digital Technology (X1), Innovative behavior (Y1) and Organizational Culture (Y2) variables.

TABLE 4. Variable Measurement Model for each Digital Technology (X1)

\begin{tabular}{cccc}
\hline Indikator & Estimate & SE & CR \\
\hline X1.1 & 0.769 & 0.082 & $9.42^{*}$ \\
X1.2 & 0.859 & 0.036 & $23.75^{*}$ \\
X1.3 & 0.890 & 0.026 & $34.69^{*}$ \\
X1.4 & 0.880 & 0.038 & $23.39^{*}$ \\
X1.5 & 0.838 & 0.055 & $15.24^{*}$ \\
\hline
\end{tabular}

$\mathrm{CR}^{*}=$ significant at .05 level, Source: Primary data processed (2019)

The model shows the following:

Measurement model Variable digital technology (X1)show that the biggest loading indicator is X1.3. (technology can support working faster and more accurately) with a loading indicator of 0.890 . While the smallest loading indicator is X1.1. (the opportunity for innovation) with a value of 0.769

TABLE 5. Measurement Models of Organizational Culture Variables (Y1)

\begin{tabular}{cccc}
\hline Indikator & Estimate & SE & CR \\
\hline Y1.1 & 0.822 & 0.059 & $13.88^{*}$ \\
Y1.2 & 0.881 & 0.059 & $14.83^{*}$ \\
Y1.3 & 0.913 & 0.032 & $28.52^{*}$ \\
\hline
\end{tabular}




\begin{tabular}{rlll}
\hline Y1.4 & 0.831 & 0.044 & $18.91^{*}$ \\
Y1.5 & 0.810 & 0.055 & $14.78^{*}$ \\
\hline
\end{tabular}

$\mathrm{CR}^{*}=$ significant at .05 level, Source: Primary data processed (2019)

Measurement model Variable Organizational Culture (Y1) also informs that the development of HR (Y1.3) has the greatest loading value that is equal to 0.913 dan and the smallest loading value is Y1.5 (the communication and coordination) of 0.810 .

TABLE 6. Innovative Behavior (Y2) Variable Measurement Model

\begin{tabular}{cccc}
\hline Indicator & Estimate & SE & CR \\
\hline Y2.1 & 0.865 & 0.050 & $17.2^{*}$ \\
Y2.2 & 0.857 & 0.038 & $22.4^{*}$ \\
Y2.3 & 0.891 & 0.037 & $24.09^{*}$ \\
Y2.4 & 0.872 & 0.037 & $23.76^{*}$ \\
Y2.5 & 0.705 & 0.128 & $5.52^{*}$ \\
\hline
\end{tabular}

$\mathrm{CR}^{*}=$ significant at .05 level, Source: Primary data processed (2019)

The Innovative Behavior (Y2) Variable measurement model also informs that giving attention to the refinement of creative ideas (Y2.3) has the greatest loading value of 0.891 and the lowest is Y2.5 (developing, testing, and commercializing innovative ideas) with a loading value of 0.705 .

\section{Hypothesis Testing Results (Structural Model Test Results)}

In the structural model, nine hypotheses of relationship between variables are tested (direct effect). 




FIGURE 2. Structural Model

The results of testing the relationship between research variables are as follows:

TABLE 7. Research Hypothesis Testing Results (Direct Effect)

\begin{tabular}{clcccc}
\hline $\begin{array}{c}\text { Hypothe- } \\
\text { sis }\end{array}$ & \multicolumn{1}{c}{ Direct Effect } & $\begin{array}{c}\text { Path } \\
\text { coeffici- } \\
\text { ent }\end{array}$ & $\begin{array}{c}\text { Standard } \\
\text { Error }\end{array}$ & $\begin{array}{c}\text { Critical } \\
\text { Ratio }\end{array}$ & Explanation \\
\hline $\mathrm{H} 1$ & $\begin{array}{l}\text { Digital Technology (X1) - } \\
\text { >Organizational Behaviour (Y1) }\end{array}$ & 0.570 & 0.114 & $4.99^{*}$ & significant \\
\hline $\mathrm{H} 2$ & $\begin{array}{l}\text { Digital Technology (X1) -> } \\
\text { Innovative Behaviour (Y2) }\end{array}$ & 0.329 & 0.115 & $2.88^{*}$ & significant \\
\hline $\mathrm{H} 3$ & $\begin{array}{l}\text { Organizational Behaviour (Y1)-> } \\
\text { Innovative Behaviour (Y2) }\end{array}$ & 0.517 & 0.103 & $5.02^{*}$ & significant \\
\hline
\end{tabular}

$\mathrm{CR} *=$ significant at .05 level, Source: Primary data processed (2019)

In addition to testing the direct effect, multivariate modeling is also known as an indirect effect. Indirect effect is the product of 2 (two) direct effects. An indirect effect is declared significant if the two direct influences that shape it are significant, if one or both of them are not significant then the effect is not necessarily insignificant. The following are the results of indirect effects

TABLE 8. Results of Research Hypothesis Testing (Indirect Effects)

\begin{tabular}{cllll}
\hline $\begin{array}{c}\text { Hypo } \\
\text { thesis }\end{array}$ & \multicolumn{1}{c}{ Relation } & Coefficient & Explanation & $\begin{array}{c}\text { Conclu- } \\
\text { sion }\end{array}$ \\
H4 & $\begin{array}{l}\text { Digital Technology (X1) } \\
\text {->Organizational } \\
\text { Behaviour (Y1)-> }\end{array}$ & 0.295 & $\begin{array}{l}\text { Digital Technology (X1) - } \\
\text { >Organizational (Sig.) }\end{array}$ & $\begin{array}{l}\text { significa } \\
\text { nt }\end{array}$ \\
\hline
\end{tabular}




\begin{tabular}{ll}
\hline $\begin{array}{l}\text { Innovative Behaviour } \\
(\mathrm{Y} 2)\end{array}$ & Behaviour (Y1)-> \\
& $\begin{array}{l}\text { Innovative Behaviour (Y2) } \\
\text { (Sig.) }\end{array}$ \\
\hline
\end{tabular}

Source: Primary data processed (2019)

Based on the above calculation, Hypothesis 1,2,3, and 4 are accepted.

\subsection{Digital Technology has a positive and significant effect on Organizational Culture.}

Digital Technology is a means and infrastructure of the system to obtain, transmit, process, interpret, store, organize, and use data meaningfully to the organization, this is seen by Digital technology indicators that have the most influence are digital indicators supporting technology to work faster and more accurately and Organizational culture is a social glue that remembers members of the organization so that organizational culture can provide stability for an organization.

\subsection{Digital technology has a positive and significant effect on innovative behaviour.}

The development of digital technology is able to sustain the growth of the creative economic environment and strengthen the economy and the added value of the company is strengthened by the Indicator innovative behaviour that has the most influence is the attention to perfecting creative ideas. Innovative behaviour means creating meaningful changes that meet needs. Innovation means using what we know to help others grow and live a better life.

3.6 Organizational Culture has a positive and significant role in innovative behaviour. Organizational culture influences innovative behavior with the biggest effect indicator is the Company is developing HR to get optimal work results. The impact of cultural behavior caused by organizational commitment to the consequences of innovative behavior (innovative behavior) in the organization. Therefore organizational culture has a major role in building the innovation process in the company. A positive climate of organizational innovation built through organizational culture can affect company commitment. There are 3 (three) phases in carrying out the innovation process, as follows: 1. Generating ideas, the involvement of individuals and teams in generating ideas to improve existing products, processes and services and create something new. 2. Harvesting ideas, involves a group of people to gather ideas that already exist and evaluate these ideas. 3. Developing and implementing ideas, developing ideas that have been collected and then implementing those ideas.

\subsection{Digital technology has a positive and significant role in innovative behaviour through Organizational Culture.}

Digital Technology is increasingly important in the business world because of its ability to accelerate the movement and acceleration of business. But business acceleration will not be realized if it is not supported by organizational innovation behaviour. Innovative behaviour is the ability of individuals to change the way work in the form of adopting new work procedures, practices and techniques in completing tasks and work. Innovative behaviour is not solely influenced by innate or internal factors. Organizations must also be aware that a climate that supports individual activities can encourage innovation. Furthermore, the positive role of digital technology on organizational culture is that there is an increase in speed, accuracy, and convenience that provides time, energy and cost efficiency to the company [18].

\section{CONCLUSIONS}


In conclusion in this research are Digital Technology has a positive and significant effect on Organizational Culture. Digital technology has a positive and significant effect on innovative behaviour. Organizational Culture has a positive and significant role in innovative behaviour. Digital technology has a positive and significant role in innovative behaviour through Organizational Culture

In the context of human empowerment, to produce professional staff and high integrity, companies must refer to the standards set. Therefore the authors suggest the need to improve implementation related to: 1) Digital Technology: automation in simplifying the work system; 2) innovative behaviour: developing, testing, and commercializing innovative ideas; and 3) Organizational Culture: good communication and coordination between employees.

\section{REFERENCES}

[1] Z. Theory, How, Business, J. Meet, W. G. Challenge, and Ouchi, "Tinjauan Mata Kuliah," oleh Edgar H. Schein, vol. 9, no. 1, pp. 1-54.

[2] E. Hartl and T. Hess, "The role of cultural values for digital transformation: Insights from a delphi study," AMCIS 2017 - Am. Conf. Inf. Syst. A Tradit. Innov., vol. 2017Augus, no. January 2019, 2017.

[3] O. Nathaniel C, "Impact of Organizational Culture and Technology on Firm Performance in the Service Sector," Commun. IIMA, vol. 13, no. 1, pp. 69-82, 2013.

[4] S. Dasgupta and B. Gupta, "Organizational Culture and Technology Use in a Developing Country: An Empirical Study,” Proc. SIG GlobDev Third Annu. Work. Saint Louis, USA, no. 2003, pp. 61-76, 2010.

[5] K. Lukoto and K. Y. Chan, "The perception of innovative organisational culture and its influence on employee innovative work behaviour," PICMET 2016 - Portl. Int. Conf. Manag. Eng. Technol. Technol. Manag. Soc. Innov. Proc., no. September 2016, pp. 972-977, 2017.

[6] P. T. Nham, H. P. Pham, and N. Nguyen, "The Impact Of Organizational Culture On Innovation Acitivities - The Case Of X Corporation In Vietnam," J. Glob. Manag. Res., no. 1990 , pp. 29-36, 2014.

[7] J. Zheng, G. Wu, H. Xie, and H. Li, "Leadership, organizational culture, and innovative behavior in construction projects: The perspective of behavior-value congruence," Int. J. Manag. Proj. Bus., vol. 12, no. 4, pp. 888-918, 2019.

[8] L. C. Nawangsari and A. H. Sutawidjaya, "The Effect of Styles of Leadership, Conflict Management and Communication Organization to Team Performance," Int. J. Humanit. Soc. Sci. Educ., vol. 5, no. 7, pp. 1-8.

[9] Y. Zhou, C. Shu, W. Jiang, and S. Gao, "Green management, firm innovations, and environmental turbulence,” Bus. Strateg. Environ., vol. 28, no. 4, pp. 567-581.

[10] J. P. J. Jong, UvA-DARE ( Digital Academic Repository) Individual innovation : the connection between leadership and employees' innovative work behavior The Connection Between Leadership and. 2007.

[11] T. M. Amabile, "A Model of Creativity and Innovation in Organizations," Research in Organizational Behavior, vol. 10, no. 1. p. 123, 1988.

[12] E. C. Martins and F. Terblanche, "Building organisational culture that stimulates creativity and innovation,” Eur. J. Innov. Manag., vol. 6, no. 1, pp. 64-74.

[13] R. A. Sularso, "Pengaruh Penerapan Peran Total Quality Management Terhadap Kualitas Sumberdaya Manusia," J. Manaj. dan Kewirausahaan, vol. 6, no. 1, pp. 7281, 2004.

[14] M. F. Rice, "Information and Communication Technologies and the Global Digital 
Divide," Comp. Technol. Transf. Soc., vol. 1, no. 1, pp. 72-87, 2003.

[15] R. Vuorikari, Y. Punie, S. Carretero, and L. Van Den Brande, DigComp 2.0: The Digital Competence Framework for Citizens. 2016.

[16] A. Andersson and A. Grönlund, "A Conceptual Framework for E-Learning in Developing Countries: A Critical Review of Research Challenges," Electron. J. Inf. Syst. Dev. Ctries., vol. 38, no. 1, pp. 1-16, 2009.

[17] "GENERALIZED STRUC IT RED COMPONENT ANALYSIS HEUNGSUN HWANG HEC MONTREAL YOSHIO TAKANE Partial least squares ( Wold , 1966 , 1973,1982 ) is employed for path analysis with compo- nents or weighted composites of observed variables . Partial least squa," vol. 69, no. 1, pp. 81-82, 2004.

[18] A.Warokka, H. Sjahruddin, S. Sriyanto, E. Noerhartati, K. Saddhono. "Digital marketing support and business development using online marketing tools: An experimental analysis". International Journal of Psychosocial Rehabilitation. Vol. 24 no. 1 pp. 1181-1188. 2020 